\title{
Lightsticks cause adverse effects on behavior and mortality of marine mysids Promysis atlantica
}

\author{
Caio Cesar-Ribeiro ${ }^{1}$ \\ ${ }^{1}$ Laboratório de Ecotoxicologia, Centro Universitário Monte Serrat, Santos, SP, Brazil \\ Corresponding author: Caio Cesar-Ribeiro (caiocribeiro@ hotmail.com)
}

\begin{abstract}
Lightsticks baits are discharged into the ocean after their use in longline fishing. The traditional Brazilian community of Costa dos Coqueiros, Bahia, uses lightsticks as a medicine for rheumatism, vitiligo, and mycoses. It may affect marine life when its content leak into the ocean. This study assessed the toxicity identification and evaluation (TIE) of lightsticks constituents on marine mysids Promysis atlantica. The internal solution was dissolved in seawater with ethanol. The lethal concentration of the contaminant that causes mortality in $50 \%$ of the exposed population $\left(\mathrm{LC}_{50}\right)$ after $3 \mathrm{~h}$ was $0.001 \%$, demonstrating that lightstick is exceptionally toxic because low concentrations cause mortality to mysids $P$. atlantica. Due to lightsticks' high toxicity, the TIE baseline was $0.005 \%$ SSE (stock solution ethanol), and the selected endpoints were behavior and lethality. The sample submitted to aeration presented a significant reduction $(P<0.05)$ in toxicity $(0.005 \%$ SSE) because the volatile compounds caused the toxic effect. The sodium thiosulfate treatment induced an insignificant decrease in toxicity. Thus, a new assay was conducted considering aeration and sodium thiosulfate. This combination reduced lightstick toxicity compared to the baseline lightstick, suggesting that volatile compounds and oxidants were responsible for toxicity; even in low concentrations, lightstick can promote significant behavior changes and deleterious effects. It is recommended to create new mechanisms to inspect fishing vessels, thus avoiding the improper disposal of attractors at sea and common garbage.
\end{abstract}

Keywords: Promysis atlantica; mysids; lightstick; TIE; marine pollution; ecotoxicology

\section{INTRODUCTION}

Among the marine pollution, the contamination by solid residues has been worrying the world (Windom 1992), which are included the lightsticks that are luminous beacons used by fishing vessels to catch swordfish (Xiphias gladius) and some species of tuna (Thunnus albacares, T. atlanticus). These lightsticks are attached to the secondary lines, accompanying each hook to attract fish, thus increasing baits efficiency in longline fishing; these types of attractors are used in large quantities in commercial fisheries (Hazin et al. 2005).

The lightstick glows from a chemiluminescent reaction between two compounds that are kept separate by a glass ampoule. When the tube is bent, light emission arises from the chemiluminescent reaction of oxalate esters with hydrogen peroxide in a viscous solvent, catalyzed, and photosensitized by a fluorescent polycyclic aromatic hydrocarbon (PAH). In Araújo et al. (2015), they analyzed the components of lightstick in gas chromatography-mass spectrometry GC-MS identifying 19 substances in the water-soluble fraction of the lightsticks, such as dibutyl phthalate (DBP) and dimethyl phthalate (DMP), elements considered carcinogenic to the human being (Cassee et al. 1999).

In Brazil, the international non-governmental organization (NGO) Global Garbage executed significant efforts to assess such a problem by collecting and identifying marine litter in beaches from Bahia State (Cesar-Ribeiro \& Palanch-Hans 2010, Cesar-Ribeiro et al. 2017). As a result, it was possible to identify various debris strongly related to marine vessels as the primary garbage source, potentially harmful to aquatic organisms as the lightsticks, the target object in this study. It was reported that in distant places, local populations collected lightsticks from the beaches and tried to use the tube content as suntan lotion or for treatment of

Corresponding editor: Luis Miguel Pardo 
vitiligo and even mycoses (Cesar-Ribeiro \& PalanchHans 2010, Cesar-Ribeiro et al. 2017). After drifting to the shore, elevated temperatures and solar irradiation indicated the presence of reactive electrophiles and increased cyto and genotoxic potential in human cells forming mutagenic lesions (Oliveira et al. 2014). Therefore, we investigated the toxicity of lightsticks collected on Bahia beaches (Brazil).

The isolation of hydrophilic compounds, i.e. oxalate ester, oxygen peroxide, and the salicylic acid; and hydrophobic compounds: PAH provided evidence of higher toxicity levels in the supernatant fraction that caused chronic toxicity (abnormality of pluteus larvae development) on sea urchins, Echinometra lucunter and Lytechinus variegatus (Cesar-Ribeiro \& PalanchHans 2010, Cesar-Ribeiro et al. 2017).

Mysids and specific testing procedures have become accepted in aquatic toxicology; acute and chronic toxicity tests with mysids are becoming common (Nimmo et al. 1978). Attempts have been made to use mysids as test organisms in behavioral, physiological, nutritional, and food-chain studies. They are sensitive or more sensitive to toxic substances than other marine species tested (Nimmo \& Hamaker 1982). Mysids inhabit pelagic and demersal environments, varying from $2 \mathrm{~mm}$ to $8 \mathrm{~cm}$ in length and feeding on suspended solids, and are considered omnivorous. They have a developed carapace covering the thorax, and pereopods are biramous and used to swim while pleopods are often reduced; in males, pleopods are modified for reproduction (Brusca \& Brusca 2003).

Mysids are omnivores and feed on phytoplankton, zooplankton, and organic detritus. Consequently, they can potentially structure zooplankton communities and influence the structure of phytoplankton and meiofaunal communities. Mysids often progressively replace copepods in the diet of many postlarval and juvenile commercial fish species and may serve as prey for more giant crustaceans, marine mammals, or wading birds (Verslycke et al. 2004). As fish accumulate toxic products from food in their tissues, any contamination of Mysidacea can have severe consequences for the ecosystem because they are components of several fish diets (Phan et al. 1994). They also have vertical migration behavior with the potential for rapid transport of toxic substances from the surface to marine sediments (Phan et al. 1994).

Mysids are sensitive to some chemical contaminants at environmentally relevant concentrations. Therefore, they have been used in regulatory toxicity testing for more than 40 years, and they have been used successfully to measure various sublethal toxicant effects, such as growth, swimming capability, feeding behavior, molting, energy budget, reproduction, sexual maturity, and vitellogenesis (Verslycke et al. 2004).

Generally, the most pronounced effect in acute tests is death, although unusual behavioral activities could be observed (Nimmo \& Hamaker 1982). In ecotoxicological testing, sub-lethal approaches have increased, focusing on short-term tests, as they are considered more ecologically relevant (USEPA 2002). There is an increasing need to develop reliable methodologies for chronic toxicity testing using tropical species because there is evidence regarding the differences between tropical and temperate ecosystems (Daam \& Van den Brink 2010, Figueiredo et al. 2016). Unfortunately, there are few standardized ecotoxicological assays for aquatic marine species in Brazil, and the most commonly used are based on acute toxicity responses (Krull \& Barros 2012).

According to the Environmental Protection Agency (EPA 1991, 1992), the toxicity identification and evaluation (TIE) method may play a significant role in identifying compounds responsible for toxicity. TIE phase I aims to characterize the physical and chemical nature of the sample compounds responsible for their toxicity through manipulations or chemical treatments and toxicity tests. Fractions of this sample can be subjected to the following physical and chemical treatments: addition of a chelating agent, which is complexed to metal ions; aeration to reduce volatiles such as VOCs (volatile organic compounds); addition of sodium thiosulfate, which reduces oxidizing species, such as $\mathrm{Cl}_{2}$ and $\mathrm{Cr}$ (VI); filtration, which removes suspended particles and substances whose solubility is affected by the $\mathrm{pH}$ of the medium; and others. After phase I, the class or classes of substances responsible for the total toxicity of the sample are clearly defined. Identifying toxic substances is a fundamental step in understanding the toxicity causes in complex samples and removing them or reducing their concentrations to acceptable levels (Costa et al. 2008). Therefore, the present study was designed to address the toxic effect of lightsticks on mysids Promysis atlantica to determine the group of compounds that can cause a deleterious effect on marine life.

\section{MATERIALS AND METHODS}

Costa dos Coqueiros $\left(15^{\circ} 54^{\prime} \mathrm{S}, 38^{\circ} 20^{\prime} \mathrm{W}\right.$ to $11^{\circ} 34^{\prime} \mathrm{S}$, $37^{\circ} 47^{\prime} \mathrm{W}$ ) is formed by seven municipalities located in the north of the Salvador, Bahia, Brazil; in this context, it should be noted that the coast of Costa dos Coqueiros is one of the most sought after tourist areas in the state. Furthermore, it should not be forgotten that this region of almost $200 \mathrm{~km}$ of coastline is home to one of the 
main spawning pockets of sea turtles in Brazil (Marcovaldi \& Marcovaldi 1999). With the support of the German NGO Global Garbage, a scientific hike was undertaken from 14 to 31 July 2007, along almost 200 $\mathrm{km}$ of all the Costa dos Coqueiros beaches. A total of 2554 tubes of luminous attractors were collected by hand, of which $34 \%$ were opened, and $63 \%$ were still closed. An average of 13 lightsticks per km was found at the beaches in the Coqueiros coast. The orange color tubes were taken to the laboratory, where they were opened and used to prepare the stock solution used in the toxicity tests (Cesar-Ribeiro \& Palanch-Hans 2010, Cesar-Ribeiro et al. 2017). The immiscible compounds were extracted through the dissolution of $0.1 \mathrm{~mL}$ of lightstick fluids in $100 \mathrm{~mL}$ of filtered seawater (salinity of 35) with ethanol $0.5 \%(\mathrm{v} / \mathrm{v})$ as a solvent [stock solution ethanol (SSE 0.1\%)].

\section{Toxicity identification evaluation - phase I}

The TIE is divided into phase 1: toxicity characterization procedures; phase 2: toxicity identification procedures; phase 3: toxicity confirmation procedures (EPA 1991, 1992). In this study, some procedures in the TIE protocol for phase 1 were adapted. It was executed an ecotoxicological test in different concentrations: $0.0001 ; 0.0005 ; 0.001 ; 0.005 ; 0.01 ; 0.05$ and $0.10 \%$, to access the $\mathrm{LC}_{50}$ (lethal concentration of the contaminant that causes mortality in $50 \%$ of the exposed population) after $3 \mathrm{~h}$ of exposure, using 10 individuals per replicate and four replicates per concentration/treatment. The concentration used in the TIE baseline was $0.005 \%$ of the SSE; based on previous experiments, it was noticed that after $3 \mathrm{~h}$ of exposure, the first concentration with $100 \%$ mortality was $0.005 \%$.

The procedures for sample treatment consisted of the addition of $300 \mu \mathrm{L}$ of ethylenediaminetetraacetic acid (EDTA) $(2.5 \% \mathrm{~m} / \mathrm{v})$ to each chamber to chelate the divalent metals; a $3 \mathrm{~h}$ period is necessary for complete reaction and complexation; the addition of $500 \mu \mathrm{L}$ of sodium thiosulfate $(1.5 \% \mathrm{~m} / \mathrm{v})$ in each test chambers for $1 \mathrm{~h}$ to reduce the oxidants; aeration for $1 \mathrm{~h}$ to eliminate or minimize the volatiles, and filtration through a 0.45 $\mu \mathrm{m}$ membrane to remove the suspended material. However, the tests were run on a single concentration considered toxic, and instead of making serial dilutions and comparing the $\mathrm{LC}_{50}$, the mortality rates were compared among treatments. Besides mortality, an alternative endpoint for the experiments was the behavior. The exposed mysids tended to move towards the surface, which was interpreted as an attempt to avoid contaminants or minimize contact. The endangered animals' response was observed hourly, and the number of individuals close to the surface was recorded. Blank tests were used for thiosulfate and EDTA treatments to check for possible interferences in the results. They were not necessary for filtration and aeration treatments since the water used in the experiments was previously filtered and aerated. Regarding the solvent, blanks with ethanol were used as well.

After preparation, baseline and treated samples were evaluated through the acute and chronic toxicity test with mysids Promysis atlantica (Tattersall 1923), adapting the protocol described by ASTM (1992), and CETESB (1992), Badaró-Pedroso et al. (2002).

The mysids were collected at the Lamberto Beach in Ubatuba, SP $\left(23^{\circ} 29^{\prime} 45^{\prime \prime} \mathrm{S}, 4^{\circ} 06^{\prime} 41^{\prime \prime} \mathrm{W}\right)$ and acclimated for $24 \mathrm{~h}$ in filtered seawater (salinity 35, temperature $25^{\circ} \mathrm{C}$ and $\mathrm{pH}$ 7.8). Then, the mysids were exposed to the different lightstick manipulations in 200 $\mathrm{mL}$ glass test chambers. Four replicates were prepared per treatment, containing 10 individuals each. The acceptability percentage of effects in control was $10 \%$ of mortality. Physical and chemical parameters such as temperature, salinity, and oxygen were controlled with a YSI probe and $\mathrm{pH}$ with a digital $\mathrm{pH}$ meter; the parameters were kept similar to the environment where mysids were collected. During the bioassay, individuals were kept at $25 \pm 2{ }^{\circ} \mathrm{C}$, salinity of 35 , and a $12 \mathrm{~h}$ photoperiod (12 h light: $12 \mathrm{~h}$ dark). In addition, dissolved oxygen, salinity, and $\mathrm{pH}$ were measured; at the end of the test, surviving organisms were counted, and all the procedures followed the recommendations of the Brazilian Association of Standards Techniques NBR 15.308 (ABNT 2011).

\section{Statistical analysis}

Data from experiments were checked for normality and homoscedasticity and then subjected to an analysis of variance (ANOVA) followed by the Tukey test $(P<$ $0.05)$. Even after data transformation, the nonparametric test Kruskal-Wallis was applied in BIOSTAT 5.0 software.

\section{RESULTS}

The $\mathrm{LC}_{50}-3 \mathrm{~h}$ calculated was $0.001 \%$, demonstrating that lightstick is exceptionally toxic because low concentrations cause mortality to mysids Promysis atlantica (Fig. 1). The results obtained in TIE phase 1 to mysids $P$. atlantica did not show significant mortality in controls and baseline samples (lightstick); as expected, filtration and EDTA addition did not reduce mortality.

In Figure 2, the sample submitted to aeration presented a significant reduction $(P<0.05)$ in toxicity 


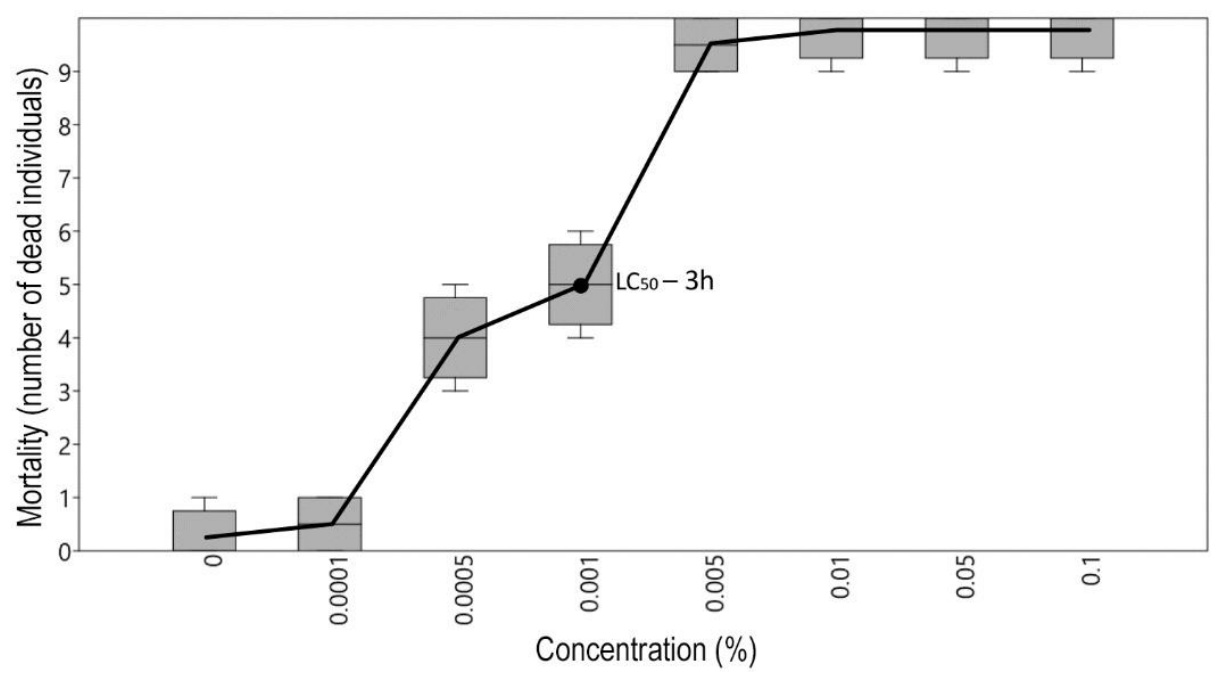

Figure 1. Boxplot of lethal concentration causes mortality in 50\% of the exposed population (LC ( $_{50}$ ) of mysids Promysis atlantica after three hours of exposure to lightstick (different concentrations \%). Data are expressed as mean of individuals \pm standard error.

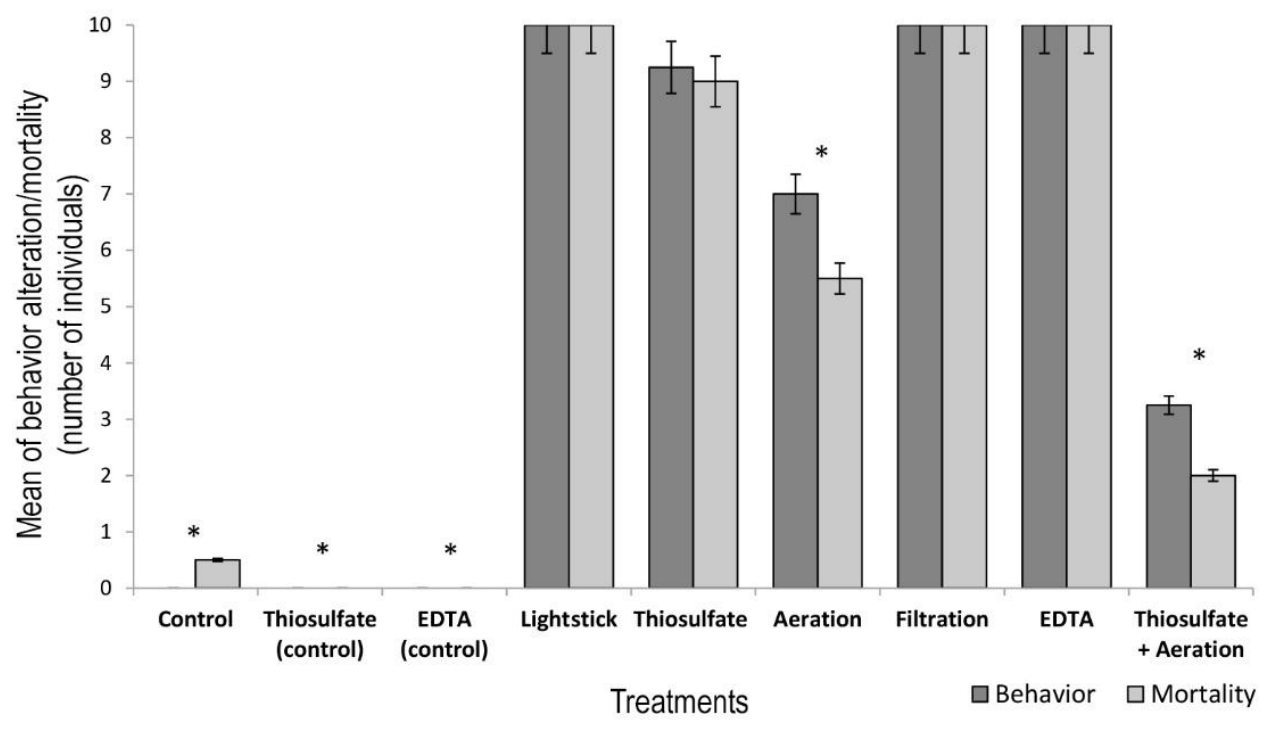

Figure 2. Toxicity identification and evaluation phase 1 represents the stock solution ethanol behavior and mortality tests of lightstick to mysids on different treatments after $3 \mathrm{~h}$. Data are expressed as mean of individuals \pm standard error. $* A$ least significant difference to baseline (lightstick concentration $0.005 \%$ ).

(0.005\% SSE) because the volatile compounds caused the toxic effect. On the other hand, the sodium thiosulfate treatment induced an insignificant reduction in toxicity. Thus, a new assay was conducted considering aeration, sodium thiosulfate, and their combination to provide more information on if and how oxidant or volatiles compounds could be responsible for the toxicity. As a result, the combination of thiosulfate and aeration treatments significantly reduced lightstick toxicity compared to the baseline lightstick.
The migratory behavior of mysids toward the chamber surface showed a similar mortality result. However, differences between treatments were not expressive; this type of observation was also helpful in identifying potential toxicity sources. Comparing the mortality results with the behavioral changes was possible to verify a Pearson correlation of $\mathrm{r}=0.99(P<$ $0.0001)$, demonstrating that the behavioral changes occurred as prior evidence of mortality. In Figure 3, the behavior effect during the $3 \mathrm{~h}$ of exposure, after one 


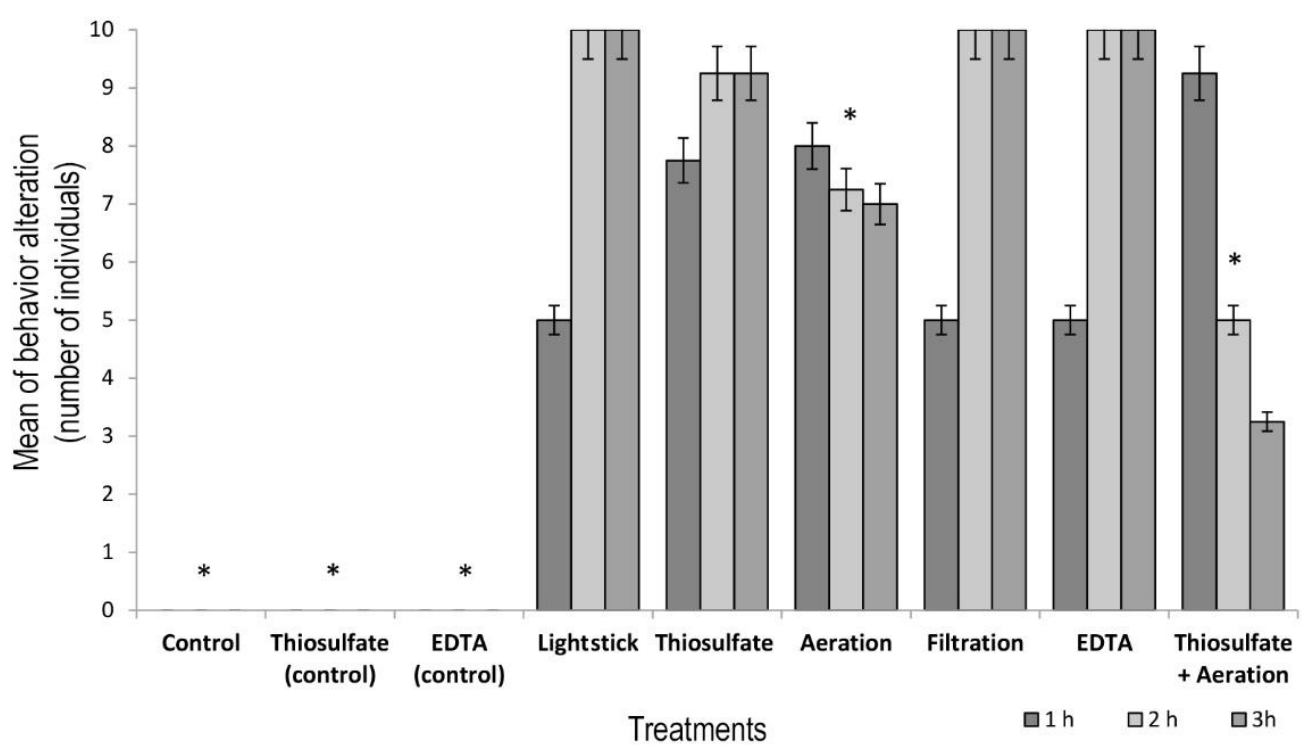

Figure 3. Toxicity identification and evaluation phase 1 represents the stock solution ethanol toxicity tests (behavior alteration) of lightstick to mysids on different treatments and evaluations (1,2, and $3 \mathrm{~h})$. Data are expressed as the mean of individuals \pm standard error. *A least significant difference to baseline after $3 \mathrm{~h}$ (lightstick concentration $0.005 \%$ ).

hour, was impossible to watch the least significant difference to baseline. After 2 and $3 \mathrm{~h}$, the treatment of aeration and the sum of aeration and thiosulfate significantly reduce the effect compared to the baseline.

\section{DISCUSSION}

Cripe et al. (2000) assessed the effects on survival, growth, reproduction, and behavior of Americamysis bahia upon exposure to sediments from Corpus Christi Bay. The results confirmed that the liquid inside the lightsticks is exceptionally toxic and may cause adverse marine life effects, causing mortality in mysids in small concentrations $(0.005 \%$ of SSE); the behavioral changes occurred as prior evidence of death. Nonetheless, lightsticks created a set of responses in marine organisms exposed to them, from mortality to behavioral changes, which shows that they represent a significant concern as a pollutant. Commonly, functional traits are used as ecological endpoints, as they relate directly to organism function and survival. Therefore, looking at different endpoints is crucial to not only accurately evaluating deleterious effects within laboratory conditions.

The TIE phase 1 adaptation indicated that the leading chemical groups responsible for lightstick toxicity were oxidable compounds - hydrogen peroxide - and volatiles - PAH (9,10 diphenyllanthracene, perylene, rubrene). They considered their composition, including ester-oxalates, 9,10 diphenyllanthracene, perylene, rubrene, and di-n-butyl phthalates. At the same time, dimethyl phthalate (DMP), diisobutyl phthalate (DIBP), butyl benzoate, butyl 2-ethylhexyl phthalate, diethyl phthalate (DEP); monomethyl phthalate, phthalic anhydride, 1-pentanol; tert-butyl isopropyl ether, n-butyl acetate, butyl butanoate, methyl benzoate, butyl methyl phthalate, benzenesulfonic acid 4-methyl butyl ester, t-butyl hydrogen phthalate, butyl cyclohexyl phthalate, and mono-2ethylhexyl phthalate and trichlorosalicylic acid content were identified in the lightsticks ampoules (Araújo et al. 2015). According to Oliveira et al. (2014), who analyzed the same samples from discharged lightsticks in the beaches of Costa dos Coqueiros, collected by the NGOs Global Gargabe and Capitães da Areia, identifying in the internal solution: hydrogen peroxide; rubrene (5, 6,11,12-tetraphenylnaphthacene; di-n-butyl phthalate, bis (2,4,6-trichlorophenyl) oxalate (TCPO) and 9,10-diphenylanthracene (DPA); and external solution: dimethyl phthalate and sodium salicylate. This compound group was known for its high toxicity in tests with aquatic organisms, like marine crustaceans, mysids, fairy shrimps, amphipods, and harpacticoid copepods (Mayer \& Sanders 1973, Lindén et al. 1979).

Besides mortality, exposed mysids showed unexpected responses in the test chamber, such as vertical migration, which was considered a sub-lethal behavioral response. However, this endpoint followed the same trend as mortality. Observational studies suggest that phthalates have antiandrogenic action in humans (Fontenele et al. 2010). PAH are formed by two 
Table 1. Comparison of the lightstick toxicity evaluated in different marine invertebrates, methodologies, and fractions.

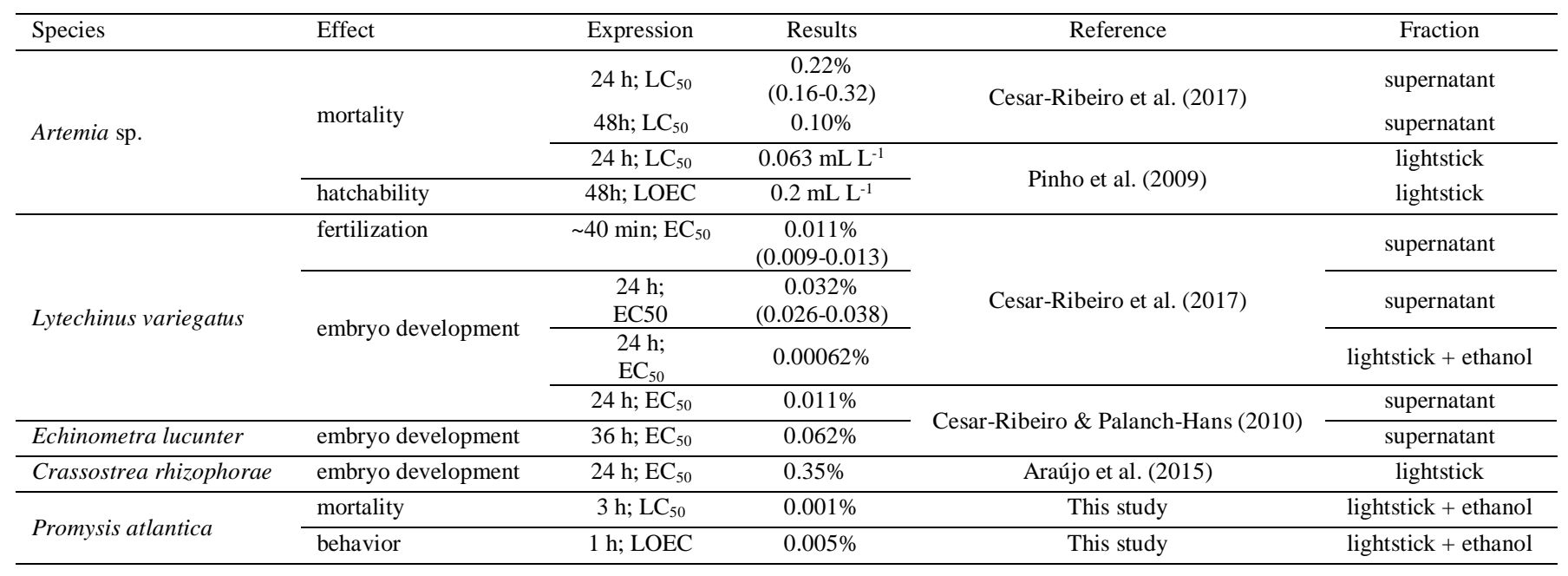

or more benzene rings ordered in a linear, angular, or grouped manner, being hydrophobic and quite resistant to microbiological biodegradation considerably persistent in the environment (Bidleman 1988). The other group of chemicals associated with lightstick toxicity is formed by PAHs (Cesar-Ribeiro et al. 2017). Accor-ding to Lee \& Nicol (1978), hydrocarbons are fat-soluble and tend to be absorbed across cell membranes, where there are higher concentrations of phospholipids. Once incorporated, they can cause changes in enzy-matic processes, membrane transport, and physic destabilization.

Adams et al. (1995) tested the toxicity effects of 10 phthalate esters to crustaceans, including mysid shrimp, and only the low molecular weight phthalate esters (examples: benzyl butyl phthalate BBP, dimethyl phthalate DMT and dibutyl phthalate DBP) were acutely toxic to mysids below their limits of water solubility. The mysid shrimp appear to be more sensitive than other aquatic invertebrate species exposed to phthalates (EG\&G Bionomics 1984). There are limited chronic toxicity data for saltwater invertebrate species with phthalate esters (Staples et al. 1997). Some authors suggest that higher molecular weight phthalate esters are not toxic to saltwater invertebrates, but the phthalates with low molecular weight are highly toxic to mysids (Suggat \& Foote 1981, Springborn-Bionomics 1984).

The interaction between toxic or polluting elements is complex and depends on the components of the mixture and the affected organism (Wong \& Pak 2004). Enserink et al. 1991 suggest that mixtures involving a wide range of chemical elements produce additive interaction, but binary and ternary mixtures become unpredictable. Macinnes (1980) also found that the degree of synergism increases as concentrations in mixtures increase. However, this approach becomes increasingly complex due to the exponential multiplication of the number of chemicals in the lightstick mixture (Cassee et al. 1999).

Table 1 compares the toxicity of lightsticks in different marine species. According to Pinho et al. (2009), the content of the lightsticks proved to be toxic in the survival of Artemia sp. nauplii; the $\mathrm{LC}_{50}$ was $0.063 \mathrm{~mL} \mathrm{~L}^{-1}$. Cesar-Ribeiro \& Palanch-Hans (2010) considered the liquid contained in the tubes collected on the beaches to be potentially toxic because they cause deleterious effects on the larval embryo development of sea urchins Echinometra lucunter $\left(\mathrm{EC}_{50}\right.$ effective concentration of the contaminant that causes an alteration in $50 \%$ of the exposed individuals, $36 \mathrm{~h}=0.062 \%)$ and Lytechinus variegatus $\left(\mathrm{EC}_{50}-24 \mathrm{~h}\right.$ $=0.0285 \%)$. Araújo et al. (2015) found the $\mathrm{EC}_{50}-24 \mathrm{~h}$ to embryo development of Crassostrea rhizophorae: $0.35 \%$. Cesar-Ribeiro et al. (2017) found $\mathrm{LC}_{50}-24 \mathrm{~h}$ : $0.22 \%(0.16-0.32)$ and $\mathrm{LC}_{50}-48$ h: $0.10 \%$ to Artemia sp.; and $\mathrm{EC}_{50} \sim 0$ min: $0.011 \%(0.009-0.013)$ in the fertilization $L$. variegatus, $\mathrm{EC}_{50}-24 \mathrm{~h}-0.032 \%(0.026-$ 0.038 ) in embryo development; in the supernatant fraction; and $\mathrm{EC}_{50}-24 \mathrm{~h}: 0.00062 \%$ in embryo development of $L$. variegatus in the extraction with ethanol; $24 \mathrm{~h}$. In this study, lightstick (ethanol extraction) showed to be toxic to mysids Promysis atlantica $\mathrm{LC}_{50}-3 \mathrm{~h}: 0.001 \%$ and in the behavior effect LOEC-1 h: $0.005 \%$.

\section{CONCLUSION}

The lightsticks include some potentially toxic compounds (hydrogen peroxide, PAHs, phthalates). Acute toxicity appears to be strongly connected to volatile and oxidable compounds. Even at low 
concentrations, lightsticks caused mortality in mysids, and behavioral changes occurred as prior evidence of death, which shows that they represent a significant concern as a pollutant. Environmental education projects directed to coastal populations are suggested to prevent public health problems. It is necessary to monitor marine debris discharge to avoid toxic waste from ships and continental discharges in the oceans that cause deleterious effects on marine life. It is necessary to underline the importance of cleaning the beaches and carrying out educational actions that make the population aware of the dangerous use of lightsticks. It is recommended to create new mechanisms to inspect fishing vessels, thus avoiding the improper disposal of attractors at sea and common garbage. These suggested actions for preserving the environment guarantee survival and maintenance of ecosystem diversity of the coastal zones of the state of Bahia and Brazil and the oceans in the world.

\section{ACKNOWLEDGMENTS}

The authors wish to thank the Global Garbage NGO for their financial support in the scientific hike, particularly Fabiano P. Barreto and the "Capitães de Areia" for their guidance.

\section{REFERENCES}

Associação Brasileira de Normas Técnicas (ABNT). 2011. Toxicidade aguda - método de ensaio com misidáceos (Crustacea). ABNT, Rio do Janeiro.

Adams, W.J., Biddinger, G.R., Robillard, K.A. \& Gorsuch, J.W. 1995. A summary of the acute toxicity of 14 phthalate esters to representative aquatic organisms. Environment Toxicology Chemical, 14: 1569-1574.

Araujo, M.M.S., Menezes-Filho, A., Nascimento, I.A. \& Pereira, P.A. 2015. Lightsticks content toxicity: effects of the water-soluble fraction on the oyster embryonic development. Chemosphere, 139: 73-80.

American Society for Testing and Materials (ASTM). 1992. Standard guide for conducting static and flowthrough acute toxicity tests with mysids from the west coast of the United States. ASTM International, West Conshohocken, pp. 1217-1238.

Badaró-Pedroso, C., Reynier, M.V. \& Prósperi, V.A. 2002. Testes de toxicidade aguda com misidáceos ênfase nas espécies Mysidopsis juniae e Mysidopsis gracile (Crustacea: Mysidacea). In: Nascimento, I.A., Sousa, E.C.P.M. \& Nipper, M. (Eds.). Métodos em ecotoxicologia marinha: aplicações no Brasil. Artes Gráficas e Indústria, Sao Paulo, pp. 123-139.
Bidleman, T.F. 1988. Atmospheric processes. Environmental Science \& Technology, 22: 361-367.

Brusca, R.C. \& Brusca, G.J. 2003. Invertebrates. Sinauer Associates, Sunderland.

Cassee, F.R., Suhnel, J., Groten, J.P. \& Feron, V. 1999. Toxicology of chemical mixtures. General and Applied Toxicology, 1: 303-319.

Cesar-Ribeiro, C. \& Palanch-Hans, M.F. 2010. Chronic toxicity test with sea urchin Echinometra lucunter and Lytechinus variegatus (Echinodermata: Echinoidea), exposed to lightstick - flag paternoster used for fishing surface longline. Brazilian Journal of Oceanography, 58: 71-75.

Cesar-Ribeiro, C., Costi-Rosa, H., Rocha, D.O., Baldini dos Reis, C.G., Prado, T.S., Muniz, D.H.C., et al. 2017. Lightstick: a problem of marine pollution in Brazil. Marine Pollution Bulletin, 117: 118-123.

Companhia de Tecnologia de Saneamento Ambiental (CETESB). 1992. Água do mar - teste de toxicidade aguda com Mysidopsis juniae Silva, 1979 (Crustacea Mysidacea). Norma Técnica L5251. CETESB, São Paulo.

Costa, C.R., Olivi, P., Botta, C.M.R. \& Espindola, E.L.G. 2008. A toxicidade em ambientes aquáticos: discussão e métodos de avaliação. Química Nova, 31: 18201830.

Cripe, G.M., Carr, R.S., Foss, S.S., Harris, P.S. \& Stanley, R.S. 2000. Effects of whole sediments from Corpus Christi Bay on survival, growth, and reproduction of the mysid, Americamysis bahia (formerly Mysidopsis bahia). Bulletin of Environmental Contamination and Toxicology, 64: 426-433.

Daam, M.A. \& Van den Brink, P.J. 2010. Implications of differences between temperate and tropical freshwater ecosystems for the ecological risk assessment of pesticides. Ecotoxicology, 19: 24-37.

EG\&G Bionomics. 1984. Acute toxicity of twelve phthalate esters to mysid shrimp (Mysidopsis bahia). Chemical Manufacturers Association, Washington, DC.

Enserink, E.L., Mass-Diepveen, J.L. \& Van Leeuwen, C.J. 1991. Combined effects of metals: an ecotoxicological evaluation. Water Research, 25: 679-687.

Environmental Protection Agency (EPA). 1991. Methods for aquatic toxicity identification evaluations. Phase 1. Toxicity characterization procedures. EPA/600/691/003, Washington, DC.

Environmental Protection Agency (EPA). 1992. Toxicity identification evaluation: characterization of chronically toxic effluents - Phase 1. EPA/600/6- 91/005.F, Washington, DC. 
Figuerêdo, L.P., Nilin, J., Silva, A.L., Loureiro, S. \& Costa-Lotufo, L.V. 2016. Development of a short-term chronic toxicity test with a tropical mysid. Marine Pollution Bulletin, 106: 104-108.

Fontenele, E.G.P., Alves-Martins, M.R., Pinto-Quidute, A.R. \& Montenegro-Júnior, R.M. 1988. Contaminantes ambientais e os interferentes endócrinos. Arquivos Brasileiros de Endocrinologia \& Metabologia, 54: 6-16.

Hazin, H.G., Hazin, F., Travassos, P. \& Erzini, K. 2005. Effect of light-sticks and electralume attractors on surface-longline catches of swordfish (Xiphias gladius Linnaeus, 1959) in the southwest equatorial Atlantic. Fisheries Research, 72: 271-277.

Krull, M. \& Barros, F. 2012. Key issues in aquatic ecotoxicology in Brazil: a critical review. Journal of the Brazilian Society of Ecotoxicology, 7: 57-66.

Lee, W.Y. \& Nicol, J.A.C. 1978. Individual and combined toxicity of some petroleum aromatics to the marine amphipod Elasmopus pectenicrus. Marine Biology, 48: 215-222.

Lindén, E., Bengtsson, B.E., Svanberg, O. \& Sundström, G. 1979. The acute toxicity of 78 chemicals and pesticide formulations against two brackish water organisms, the bleak (Alburnus alburnus) and the harpacticoid (Nitocra spinipes). Chemosphere, 8: 843851.

Macinnes, J.R. 1980. Response of embryos of the American oyster, Crassostrea virginica, to heavy metals mixtures. Marine Environment Research, 4: 217-227.

Marcovaldi, M.A. \& Marcovaldi, G.G. 1999. Marine turtle of Brazil: the history and structure of Projeto Tamar-Ibama. Biological Conservation, 91: 35-41.

Mayer Jr., F.L. \& Sanders, H.O. 1973. Toxicology of phthalic acid esters in aquatic organisms. Environmental Health Perspectives, 3: 153-157.

Nimmo, D.R. \& Hamaker, T.L. 1982. Mysids in toxicity testing - a review. In: Morgan, M.D. (Ed.). Ecology of Mysidacea. Developments in Hydrobiology. Springer, Dordrecht.

Nimmo, D.R., Hamaker, T.L. \& Sommers, C.A. 1978. Culturing the mysid (Mysidopsis bahia) in flowing sea water or a static system. Bioassay procedures for the ocean disposal permit program. EPA 600/9-78-010, Washington, pp. 59-60.

Received: October 22, 2020; Accepted: June 7, 2021
Oliveira, T.F., Lucila, A., De Moura, R.A., Bagattini, R., Falca, A.A., Oliveira, D., et al. 2014. Luminescent threat: toxicity of light stick attractors used in pelagic fishery. Scientific Reports, 4: 5359.

Phan, V.N., Gomes, V. \& Passos, M.J.D.A.C.R. 1994. Avaliação prévia da toxicidade de um efluente simulado derivado de petróleo sobre Promysis atlantica (Crustacea, Mysidacea). Boletim do Instituto Oceanográfico, 42: 129-141.

Pinho, G.L.L., Ihara, P.M. \& Fillmann, G. 2009. Does lightstick content pose any threat to marine organisms? Environmental Toxicology and Pharmacology, 27: 155-157.

Springborn Bionomics. 1984. Toxicity of fourteen phthalate esters to the freshwater green algae (Selenastrum capricornutum). Chemical Manufacturers Association, Washington, DC.

Staples, C.A., Adams, W.J., Parkerton, T.F., Gorsuch, J.W., Biddinger, G.R. \& Reinert, K.H. 1997. Aquatic toxicity of eighteen phthalate esters. Environmental Toxicology and Chemistry: An International Journal, 16: 875-891.

Suggatt, R.H. \& Foote, K. 1981. Comprehensive review of acute aquatic toxicity data on phthalate esters. Contract SRC TR 81-537. Final Report. Syracuse Research Corporation, Syracuse.

United States Environmental Protection Agency (USEPA). 2002. Methods for measuring the acute toxicity of effluents and receiving waters to freshwater and marine organisms. USEPA, Washington, D.C.

Verslycke, T.A., Fockedey, N., McKenney Jr., C.L., Roast, S.D., Jones, M.B., Mees, J. \& Janssen, C.R. 2004. Mysid crustaceans as potential test organisms for the evaluation of environmental endocrine disruption: a review. Environmental Toxicology and Chemistry, 23: 1219-1234.

Windom, M.L. 199. Contamination of the marine environment from land-based sources. Marine Pollution Bulletin, 25: 32-36.

Wong, C.K. \& Pak, A.P. 2004. Acute And subchronic toxicity of the heavy metals copper, chromium, nickel, and zinc: individually and in mixture, to the freshwater copepod Mesocyclops pehpeiensis. Bulletin of Environmental Contamination and Toxicology, 73: 190-196. 